\title{
An Offbeat Spatiality of the New Generation Small Housing Units in Istanbul
}

\author{
İstanbul'da Üretilen Yeni Nesil Küçük Konut Birimlerinin \\ Sıradışı Mekansalıkları Üzerine
}

\author{
Nilay ÜNSAL GÜLMEZ,' ${ }^{1}$ Türkan ULUSU URAZ ${ }^{2}$
}

\section{ABSTRACT}

This paper aims at investigating new residential trends in Istanbul accompanying the demographic change that introduces an increasing diversity of small/alternative (nontraditional/non-family) households to the housing market. Moreover, it triggers a theoretical debate on the concept of "offbeat spatiality". The paper has a twofold structure. First, the demographic change and its impacts in Istanbul and the concept of the spatiality of small housing units in relation to small /alternative household types are examined. Subsequently, the marketing strategies of three major entrepreneurs (Real Estate Investors, i.e. Nef, Dumankaya and Varyap) developed to attract small households are interpreted. Then, a limited number of offbeat schemes detected among the mostly standardized small housing production of these entrepreneurs and considered to be more appropriate for peculiar features of small/alternative households have been analyzed. The aim is to unfold the spatial potentials of such offbeat schemes for further housing demands of non-traditional households.

Keywords: Marketing strategies; offbeat spatialities, small/alternative households; small housing schemes.

\section{Introduction}

The demographic changes evidently have a great impact on the transformation of housing trends, particularly on the sizes of dwellings. To be able to comprehend the recent dynamics in the residential environment and make predictions for the future, an inquiry into the demographic structure of the urban population is fundamental. Hence, this paper aims

\section{ÖZ}

Bu yazı, İstanbul'da, küçük konut üretimindeki yeni gelişmeleri; alternatif/küçük hanehalkları ile ilgili demografik değişimler üzerinden ve mekansallık kavramı çevrevesinde geliştirilen kuramsal yaklaşım ışığında ele alır. Yazının akışı içerisinde iki temel izlek belirlenmiştir. Öncelikle istanbul'daki demografik değişim, bu değişimin Istanbul konut piyasasına olası etkileri ve bunlarla ilişkilenerek 'mekansallık' kavramları tartişılacaktrr. Ikinci olarak istanbul konut piyasasının önemli paydaşlarının (Nef, Dumankaya ve Varyap) alternatif/küçük hanehalklarını cezbetmeye yönelik pazarlama stratejileri yorumlanacak; ardından bunların ürettikleri çoğunlukla standart küçük konut şemaları arasından, ayırt edici nitelikleri olan az sayıdaki sıradışı örnek mekansalık kavramı çerçevesinde geliştirilen kuramsal yaklaşım ışığında analiz edilecektir. Amaç bu sıradışı şemaların, geleneksel çekirdek aile prototipi dışındaki hanehalklarının barınma pratikleri açısından taşıdıkları/önerdikleri potansiyelleri tarțşmaya açmaktır.

Anahtar sözcükler: Pazarlama stratejileri; sıradışı mekansallıklar; küçük/alternatif hanehalkları; küçük konut şemaları.

at investigating new residential trends in Istanbul accompanying the demographic change that introduces an increasing diversity of small/alternative (non-traditional/non-family) households to the housing market. The function of demographic data is not only to give way to quantitative changes in the housing supply such as sizes and norms of dwellings or amount of housing production per year. What is more to the

'Bahçeşehir University Faculty of Architecture and Design, Istanbul, Turkey

2Eastern Mediterranean University, Faculty of Architecture, Famagusta, North Cyprus.

Article arrival date: March 02, 2015 - Accepted for publication: August 12, 2015

Correspondence: Nilay ÜNSAL GÜLMEZ. e-mail: nilay.gulmez@arc.bahcesehir.edu.tr

๑ 2015 Yıldız Teknik Üniversitesi Mimarlık Fakültesi - ๑ 2015 Yıldız Technical University, Faculty of Architecture 
point is to be aware of the spatial needs and expectations of small/alternative households, and to trace the spatial counterparts of their peculiarities that would give way to alternative spatialities and design schemes of the dwellings.

Within this scope, the article is structured twofold. In the first part, the demographic change and its impacts in Istanbul and the concept of spatiality in relation to small /alternative household types are examined. Victor Turner's theory of "communitas" and Homi Bhabha's "liminal space" have been discussed as proliferating tools for developing a novel approach to spatiality of dwelling. Subsequently, the marketing strategies of three major entrepreneurs (Real Estate Investors, i.e. Nef, Dumankaya and Varyap) initiated to attract small households are re-considered, and a number of offbeat schemes detected among the mostly standardized small housing production of these entrepreneurs are discussed to reveal their peculiar spatial qualities. Apparently, these qualities make dwellings more appropriate for diverse characteristics of small/alternative households and understanding these non-standard schemes would pave the way for further challenges of designing housing units compatible with their needs and expectations. Consequently, this study mainly aims at stimulating ideas on how the housing market might respond better to spatial demands of the increasing number of small /alternative household types.

\section{Demographic Change and its Impacts on Housing in Istanbul}

Despite the recent state rhetoric that encourages the rise in birth rates and remarkable differentiations between regions, Turkey is a country that has almost completed the demographic transition. ${ }^{1}$ Tusiad report defines demographic transition as "a general name given to a process whereby high fertility and death rates give way to conscious control of the birth rate and a decline in the death rate". ${ }^{2}$ This transformation accompanies a change in family structures towards an increase in the number of one child families and married couples without children, while making non-traditional households (one-person households, double income no kids families/couples, single parents, house sharing flats) more visible especially in metropolises (Table 1). The demographic transition and related change in

\footnotetext{
Url 1. Recent statistics of TUIK (Turkish Statistical Institute) reveal that despite the state rhetoric that encourage families to have minimum three children, the speed of population growth has regressed to 13,3 in 2014 while it was 13,7 in 2013.

Behar, 1999, p. 18.
}

the household composition in Turkey -especially in the Western part of the country- went along with the rise in household numbers, which in due course address the increasing demand for housing. ${ }^{3}$ Istanbul, housing $18,5 \%(14.160 .467)$ of the whole population of Turkey (76 667864 ), is intrinsically the city with the maximum number of households. ${ }^{4}$

Although the small household size was not new in Istanbul, ${ }^{5}$ and household size has decreased since 1960's, the size of the housing units increased inversely proportional until 1990's. Murat Balamir sets forth this unproportionate situation by putting emphasis on the need for considering small/alternative household types. ${ }^{6}$ Only for about two decades the decrease in household size kept a steady pace with the decrease in the size of housing units. Fuat Can Gürlesel reveals that the average size of housing units has decreased $22 \mathrm{~m}^{2}$ in Turkey since $2003\left(161.8 \mathrm{~m}^{2}\right.$ in $2003 ; 155.6 \mathrm{~m}^{2}$ in 2006; $144.8 \mathrm{~m}^{2}$ in 2011). ${ }^{7}$ Despite this tendency, on the European side of Istanbul, by the year 2011, the ratio of houses whose size is below $100 \mathrm{~m}^{2}$ was only $3 \% .{ }^{8}$ It is apparent that the decrease in average household size together with the change in household composition will be the major determinants of the future housing demand. As mentioned by Robert Mugerauer, changing families and social patterns require new design solutions and one of the critical dimensions that would provide the basis for future planning and architecture is to think of people in new and changing ways. $^{9}$

For about a decade, the housing market in Istanbul has been eager to present alternatives to the non-traditional household types, especially to oneperson households and DINKS (Dual Income No Kids Families/Couples) with new concepts such as folding homes, modular units, mixed-use projects (including flats, offices and commercial spaces) or home offices, even though they do not yet seem to address all income groups properly. Ali Dumankaya sets forth significant milestones in terms of the development of the housing market in Turkey: the 1999 earthquake that triggered the urban renewal process along with the related laws and regulations encouraging the replacement of old houses with new housing projects in the

\footnotetext{
Yavuz and Yüceşahin, 2012, p. 106.

4 Gürlesel, 2012, p.63.

5 Please see Duben and Behar (1996) for the analysis of demographic structure in Istanbul in the late $19^{\text {th }}$ and early $20^{\text {th }}$ centuries (1880-1940). Duben and

Behar claims that even in 1907 the avarge household size was 3.6 in Istanbul ( p. 63). Balamir, 1996, p. 521-524. Gürlesel, 2012, p. 42-44. Gülersoy and Sarıkaya, 2011, p. 191.

Mugerauer, 1994, 183
} 
Table 1. Household Types and Percentages, (Gurlesel, 2012, p. 43 produced from the data of Household Research carried out by Turkish Statistical Institute)

\begin{tabular}{|c|c|c|c|c|}
\hline \multirow[b]{2}{*}{ Household Type } & \multicolumn{2}{|c|}{2002} & \multicolumn{2}{|c|}{2010} \\
\hline & Total & Percentage & Total & Percentage \\
\hline Total & 16446644,00 & 100,00 & $18,808,172$ & 100,00 \\
\hline One-Person & 665749,00 & 4,05 & $1,141,319$ & 6,07 \\
\hline Single/Lone-Parent & 926749,00 & 5,63 & 578,92 & 3,08 \\
\hline One-Child Family & 2620653,00 & 15,93 & $3,731,927$ & 19,84 \\
\hline Two-Child Family & 3939274,00 & 23,95 & $4,090,915$ & 21,75 \\
\hline Three-Child and More Family & 3103774,00 & 18,87 & $2,560,804$ & 13,61 \\
\hline Family Without Child & 2155506,00 & 12,86 & $2,709,183$ & 14,40 \\
\hline Patriarchal Family & 2951679,00 & 17,94 & $3,206,643$ & 17,05 \\
\hline House Sharers & 130631,00 & 0,77 & 788,46 & 4,20 \\
\hline
\end{tabular}

city center; financial crisis in 2001, the branding period between 2004-2008 when both production and purchase reached their peak; the global crisis in 2008 and the accelerating emphasis on sustainability and green buildings since 2012 along with the implementation of novel laws (reciprocity law [mütekabiliyet], consumer law, disaster law) that intend to sustain the growth of the housing sector as the impetus of economic growth. ${ }^{10}$ Dumankaya also claims that, with the land support of the state, instead of prototyped housing blocks of TOKI (Mass Housing Administration of Turkey) mostly out of context, GYOs (Real Estate Investors) may produce novel alternatives considering aesthetic aspects as well. ${ }^{11}$ Obviously, both the government and the major entrepreneurs are aware that the housing market addressing upper classes is shrinking and they need to contemplate on how to produce housing alternatives for middle/lower middle and lower income classes. We believe that this concern for middle and lower middle income groups also embraces small/alternative household types such as single parents and house sharing friends who are in demand of smaller units and who are accustomed to confine themselves to the existing housing stock mostly addressing traditional nuclear families by reducing their expectations to a minimum.

\section{Small Households, Space and Their Peculiarities}

Recently, we have come up with new approaches to housing which assert that households, their perceptions and attitudes, and the meanings that dwellings have for them should be the focus of analysis, as suggested by David Clapham. He defines the household 'as

\footnotetext{
${ }^{10}$ Dumankaya, 2013.
}

11 Dumankaya, 2013. the unit in which people consume housing and make decisions about ${ }^{\prime 12}$ and claims that although there are various definitions and ideas on the differentiation of household and family, 'the emphasis in definitions of the family is on blood or emotional ties, while the definition of a household is based on the joint consumption of housing'.13 NYC (New York City) Citizens Housing Planning Council claims that one of the reasons that prevents housing market and policy makers to develop policies and housing alternatives for constantly increasing numbers of small/alternative households especially single adults is the false consideration of 'household' as the synonymous of 'family'. ${ }^{14}$ However, each group is incredibly diverse, and those non-traditional living arrangements do not solely correspond to a transient/temporary period in the life course.

The existing literature on housing needs and expectations of small/alternative households mostly relies on the demographic, social and political aspects of the problem. One of the oldest sources is 'Household Structure and Housing Needs ${ }^{\prime 15}$ published in 1951 that focuses on investigating the household structure to be able to formulate a housing program; another one dates back to 1977 'Housing For Special Groups' that aims at demonstrating the size and scope of the housing problems of special groups. ${ }^{16}$ "Diğerleri'nin Konut

\footnotetext{
${ }^{12}$ Clapham, 2005, p. 26.

${ }^{13}$ Clapham, 2005, p. 39.

14 Url 2.

${ }^{15}$ Glass and Davidson, 1951, p. 395-420.

${ }^{16}$ United Nations, 1977. It is the proceedings of an international seminar organized by the committee of Housing, Building and Planning of the United Nations
}

Economic Commissions for Europe held in Netherlands, 8-13 November 1976.

7 Komut (ed.), 1996. Akin to Organization of United Nations, a conference has been organized in Turkey in 1996 as one of the important events preliminary to Habitat II. The papers presented has been collected in an edited book and published by TMMOB. 
Sorunları" (Housing Problems of the Others) ${ }^{17}$ that was published in 1996, has been groundbreaking in Turkey in terms of triggering the discussion on housing needs of so far overlooked groups including non-traditional household types. One of the seminal works that also addresses spatial solutions for new households is 'New Households and New Housing' that was published in 1991. ${ }^{18}$ There are studies on the housing demand and problems of specific groups such as one-person households; ${ }^{19}$ single parents; ${ }^{20}$ youth in transition to independent living ${ }^{21}$ or those in search of shared housing. ${ }^{22}$ However, there is a significant lack in the literature on the discussion of 'spatiality' regarding specific features and potentials of small/alternative household types.

We move from the point that small/alternative households pave the way for unconventional housing schemes and concepts of living since their daily routines and time-management are different than those of traditional nuclear families. Their peculiarities regarding daily life, social and physical needs, and expectations bear the potential of producing unexpectedly innovative spatialities. Furthermore, diverse features of non-traditional households in contradiction to settled norms and structures might have some relevant spatial correspondences.

Hence, to be able to conduct an analysis on spatial correspondences of peculiarities of small/ alternative households through selected offbeat schemes of new generation small housing units, first we aim to develop a theoretical base departing from seminal works of Victor Turner ${ }^{23}$ on structure and anti-structure (communitas) and Homi K. Bhabha on liminal space. ${ }^{24}$

Turner prefers to use the Latin term communitas to community "to distinguish this modality of social relationship from an area of common living" 25 and claims that "communitas emerges where social structure is not". ${ }^{26}$ He refers to opposing natures of communitas and social structure claiming that the former has 'spontaneous, immediate, concrete', and the latter has 'governed, institutionalized, abstract' nature. ${ }^{27}$ Turner states that:

"Communitas breaks in through the interstices of structure, in liminality; at the edges of structure, in marginality; and from beneath structure, in inferior-

\footnotetext{
${ }^{18}$ Frank and Ahrentzen (ed), 1991.

${ }^{19}$ Fisher and Graham, 1974, p. 163-168.

${ }^{20}$ Berger, Heintze, Naidich and Meyers, 2008, p. 934-949.

100; Després, 1993, p. 381-403

23 Turner, 1991.

${ }^{24}$ Bhabha, 2004

21 Jones, 2000, 183-184

25 Turner, 1991, p. 96

${ }^{26}$ Turner, 1991, 126.

${ }^{22}$ Heath and Kenyon, 2001, p. 83-
}

ity...... it transgresses or dissolves the norms that govern structured and institutionalized relationships and is accompanied by experiences of unprecedented potency...." ${ }^{28}$

Liminality, marginality, and inferiority are conditions that pave to way for a reformulation of the reality and existing norms. La Shure claims that manifestations to social structure: liminality, marginality and inferiority could also be expressed in spatial terms respectively as in between, on the edges and beneath. ${ }^{29}$ We believe that small/alternative households (i.e. one-person households, single parents, and DINKS) in the society -when we consider the hegemony of nuclear families in conservative societies where family ties are still strong as in Turkey and even in Istanbul- could be defined in the range of communitas. They are invisible not only spatially but also socially in the built environment. Due to their non-standard characteristics, small/alternative households are treated as concealed groups experiencing a temporary period in their life course; as the others of the society out of the streamline; and as the marginals that need to confine themselves with prototype solutions. On that account, they may easily be associated with the social concepts of liminality, marginality, and inferiority.

At that point, we shall refer to Homi Bhabha, who developed a liminality model based on the performative production of culture and suggested liminal negotiation of cultural identities. ${ }^{30}$ According to Bhabha liminal space "provide terrain for elaborating strategies... that initiate new signs of identity, innovative sites of collaboration, and contestation, in the act of defining the idea of society itself". ${ }^{31}$ The theoretical debate commenced by Bhabha is interesting for us as architects because he also attempts to search for architectural/spatial correspondence of liminal space. He gives reference to an African-American artist Renée Greenswork and defines the stairwell as a liminal space between the upper and lower areas, as a site of passage and temporal movement that also prevents 'premordial polarities' ${ }^{32}$ and provides a site of continual negotiation.

The discussion on communitas, liminal space and the related concepts help us to think outside the box and constitute a theoretical base for the analysis of offbeat spatialities in the pursuit of spatial correspondences with the peculiarities of small/alternative households. Theories of Turner and Bhabha put em-

\footnotetext{
${ }^{28}$ Turner, 1991, p. 128 -129.

${ }^{31}$ Bhabha, 2004, p. 1-2

${ }^{29}$ La Shure, 2005.
}

${ }^{30}$ Bhabha, 2004. 
phasis on the substantial potentials of the in-between conditions/positions that mostly have marginal and inferior implications. Edward Soja ${ }^{33}$ in Thirdspace while discussing the new cultural politics of differences cites Bell Hooks ${ }^{34}$ who defines marginality "as a site of resistance", and "location of radical openness and possibility" and who stresses its nourishing capacity. Marginal and inferior roles in the society may help us to criticize and dismantle the existing norms for all scales of the built environment.

We should not forget that space is a social product as indicated by Henri Lefebvre, ${ }^{35}$ and every social formation produces spatiality: physical space itself, a way of organizing it and a way of thinking about it. ${ }^{36}$ The point that spatiality embraces the act of thinking about space seems very crucial. Obviously, spatiality means more than the physical space; it also embraces living experiences and memories and relevantly becomes more important as the size of the housing units gets smaller. Small houses should not be just diminutive versions of larger units; in contrast, their spatialities should support the peculiar features of their potential users, namely small/alternative households and offer more radical, uncommon and unexpected possibilities. For instance, one-person households that have recently drawn more attention in the housing market have quite a different sense of territoriality, appropriation, privacy and attachment when compared to other groups (single parents, DINKS, house sharing friends, etc.). They do not negotiate with anyone within the house but with space itself. Moreover, they aim at compensating their loneliness at home in their close environment with their neighbors (as well as in the social media). Hence, they are more open to socialization possibilities. ${ }^{37}$ On the contrary, the members of small households encompassing more than one person (mostly two) like DINKS, house sharing friends, or single parents all need to negotiate with one another. Besides, the way they accomplish this negotiation also determines their relation with the home space and its divisions. That is also why Clapham believes that household as an entity should be the focus of housing research. He does not ignore the individual but states that especially in the case of households encompassing more than one person, the members of the household need to reconcile since they have different char-

\footnotetext{
${ }^{33}$ Soja, 1996, p. 98.

154).

${ }^{34}$ Hooks, 1990. Please see chapter Chapter 5 "Homeplace: A Site of

Resistance" (p. 41-50) and Chap- ${ }^{36}$ Roberts, 2014.

ter 15 "Choosing Margin as a ${ }^{37}$ Gülmez, 2008.

Space of Radical Opennes" (145- ${ }^{38}$ Clapham, 2005.
}

acteristics, needs, and expectations. ${ }^{38}$

Apparently, small/alternative households are becoming more aware of their peculiar spatial needs, and they are getting more interested in solutions that sustain their non-standard, non-traditional lifestyles and routines in spatial terms. Some major entrepreneurs (Real Estate Investors) have recognized this inclination; thus, they urge to influence diverse household typologies with their novel projects. The living conditions and environments of these alternative groups, the edges, small basement or ground floor flats, roof spaces and the uncanny, odd extraordinary solutions which have been widely observed in our contemporary urban environment have lately grasped a prestige in the recent projects of these Real Estate Investors. Furthermore, they substantially establish their marketing strategies on the lifestyle(s) of their potential inhabitants, especially of small/alternative households. When the recent projects of three major entrepreneurs (NEF, Dumankaya and Varyap) in the housing market are examined (18 projects in total), it is realized that their small housing units (studio flats, suites, and $1+1$ units) consist of mostly accustomed, ordinary plan schemes. They rarely propose experimental schemes that would stand for alternating settled norms. During our research, we have detected only a few projects that embrace a limited amount of offbeat solutions; hence, they partially reflect the enthusiasm headed towards lifestyle(s) in spatial sense as well, to attract their target groups basically small/alternative households.

\section{Novel Concepts and Spatial Themes Addressing Small Household Types}

Having discussed the theoretical basis of the subject, in this part of the article, first the recent housing projects of the three major entrepreneurs (NEF, Dumankaya and Varyap) substantially offering small housing units in Istanbul (18 projects in total) ${ }^{39}$ are examined in terms of their marketing strategies and lifestyle concepts that they propose. Thus, we aim at understanding the relationship between the lifestyle promises and spatiality of the proposed housing units. Then, a limited number of plan schemes, which are spatially subverted and thought to be more appropriate for peculiar aspects of small/ alternative house-

\footnotetext{
3918 projects subjected to analysis in terms of their marketing strategies and plans schemes of the housing units are: Nef merter 12, Nef Merter 13, Nef Kağıthane 03, Nef Kağıthane 08, Nef Kağıthane 10, Nef Kağıthane 11, Nef Ataköy 22, Nef points 04, Nef points 06, Nef points 98, Nef apartments; Dumankaya flex Kurtköy, Dumankaya Hi-fit, Dumankata Ritm-İstanbul, Dumankaya konsept Halkalı, Dumankaya Horizon, Dumankaya Mix; Varyap Meriden I.
} 
holds, and tend to be more personalized, are selected and analyzed. As it is stated before, the aim of the research is not to classify the plan typologies and/or end up with quantitative data but to contemplate on the concept of spatiality, to investigate the offbeat small housing schemes that go beyond the traditional ones offering alternative spatial uses and introducing new terminologies to the housing market.

\section{Marketing Strategies Proposing Lifestyles}

David Chaney, in his seminal book 'Lifestyles' defines lifestyle as 'a status grouping peculiar to modernism'. ${ }^{40}$ Moreover, he claims that this status is not only related to shared professions and privileges, but it is more about how we use some goods, spaces and times that belong to certain groups. Hence, it is about the social norms of consumerism. ${ }^{41}$ Referring to different approaches and definitions of the lifestyle concept, David Bell and Joanne Hollows put emphasis on a common aspect that all critics share 'lifestyle is now central to the organization and experience of everyday life'. ${ }^{42}$ As stated by Bell and Hollows, ${ }^{43}$ since the lifestyle media has emerged and started to dominate the agenda in 1980's, the concept of 'lifestyle' has been central to debates in relation to transformation of consumer culture and shift in the society towards post-Fordism. Contrary to Pierre Bourdieu ${ }^{44}$ who asserts that different classes exhibit different lifestyles, post-Fordist school ${ }^{45}$ claims that as mass-production has disappeared and evolved into a more flexible and specialized production, lifestyles are becoming more and more diverse and it is not possible to associate lifestyles with traditional groupings or class-related consumption patterns in the old sense. ${ }^{46}$ It is essential to creating niche markets for proliferating lifestyles in all products including housing, and Real Estate Investors in Istanbul seem to be aware of the necessity of differentiating themselves to address diverse groups. They even take the lead to present lifestyle scenarios. In this part of the article, the marketing strategies of the selected three entrepreneurs are analyzed appertaining to their lifestyle promises.

NEF entered the market in 2010 with NEF Flats Levent 163 Project with a special emphasis on innovative ideas promising to transcend the settled notions of the physical boundaries of housing units, size and con-

\footnotetext{
${ }^{40}$ Chaney, 1999, s.24

${ }^{41}$ Chaney, 1999, s.15, 24.

42 Bell and Hollows, 2006, p. 1

43 Bell and Hollows, 2006, p. 1

${ }^{44}$ Bourdieu, 1999. Please see es-

pecially Part III. Class Tastes and
}

ventional user types, and claiming that they were addressing young professionals who could pay a limited amount of money per month. ${ }^{47}$ Those professionals would in turn own their first small flats.

The firm grounds its main marketing strategy on the notion of 'breath' and 'breathing' that differentiates it from the opponents in the market, most of which appeals to status, homogeneity, family life and security. 'Being irrevocable as breathing,' suggests potential customers 'a breath' to hold on to life or to take a breath when necessary. ${ }^{48}$ 'Breathing' as a concept does not imply anything regarding the income groups or household typology but gives implicit clues about the lifestyles.

The firm has introduced the 'fold home' concept to the market as a spatial and economic innovation, which indicates that the housing block/condominium works as a constantly transforming system and the small housing units might fold when extra rooms and functions are needed. NEF claims that the needs and expectations of the potential user groups have been analyzed to determine the program of folding spaces for each project. ${ }^{49}$

Fold-home projects offer a sequential use of some extra spaces/rooms and (we believe that) they introduce a new type of embodied virtual space in-between public and private. Those folding spaces to be hired are public because every resident can use them or at least bear in mind this possibility in case of need, on the other hand, residents own them in private as long as they pay. The state of belonging they offer to their temporary residents are also diverse than that of private (living) units. In some projects (Merter 12, NEF Kağıthane 08), Nef attempts to fold the units $(1+1)$ themselves. Those projects present 'modular house' system as their novel innovation that would allow to integrate two roomed $(1+1)$ flats to end up with double and triple sized units. Thus, the firm offers an open system that would take its final form, according to the demands of the users.

The second entrepreneur selected based on its small housing production is Dumankaya that was founded in 1963. The institutional vision of Dumankaya appears as 'creating living areas that would add identity to the city'. ${ }^{50}$ The firm grounds its marketing strategy more on the scenarios of communication and puts emphasis on health and sports facilities. 'The fittest version of home' is the motto of the most recent project of

${ }^{47}$ Url 3. $\quad{ }^{48}$ Url $4 . \quad{ }^{49}$ Url $5 . \quad{ }^{50}$ Url $6 . \quad{ }^{51}$ Url 7. 
Dumankaya, 'Dumankaya-hi fit'. ${ }^{51}$ Mostly comprising of small housing units (studio flats, $1+1$ and $2+1$ units), the project offers a mobile application 'homefit' including intelligent wristband for better nutrition, calorie control and sleep, the opportunity of following statistical body data (steps, active minutes, weight, distance...) through an IQ Platform that you can load and follow all your personal health records and benefit from personal assistantship and intelligent house services. This digital platform also allows the possibility of communicating with neighbors to team up, becoming a partner in games, forming and following activities, and making reservations in floor gardens and sports and entertainment zones. Promoting a fitter life, Home-fit is announced as the 'the first and only healthy living concept' in Turkey. ${ }^{52}$ However, this attempt of distinguishing itself in the market via lifestyle is very rarely reflected on plan schemes.

In Dumankaya projects, which mostly embrace small housing units such as Flex Kurtkoy, Adres Istanbul, and Dumankaya Hi-fit, although the plan schemes are not very innovative and original, in terms of socialization possibilities, scenarios for the use of common spaces (such as flex roof at Flex Kurtkoy) and the possibilities of self-development, there are innovative ideas to cope with the timelessness, constraints of transportation and feeling of loneliness experienced by city-dwellers, particularly non-traditional households. Moreover, some projects seem to address specific user groups such as Flex Kurtkoy including solely home offices or Adres Kampus projects (East/West/ South and Panorama) including etude/study rooms, reading and play rooms mostly appealing to university students.

The Varyap Construction firm established in 1975 has come to the fore with the huge scale Varyap Meridian project constructed in Ataşehir. The project has been presented as 'a design tale at the heart of the Anatolian side'. The concept has been explained twofold as making use of both inspiration and change. The iconic design of the project, sources of inspiration such as the silhouette of Istanbul, its relation with nature, and sustainability appear as the most dominant tools of marketing. ${ }^{53}$

In comparison, it might be said that all three entrepreneurs (Real Estate Investors) focus on building and selling a lifestyle. Dumankaya builds its strategy mainly on communication and intelligent home systems; the scenarios they offer for communal spaces and com-

\footnotetext{
${ }^{52}$ Url $8 . \quad{ }^{53}$ Url 9.
}

munication possibilities are significant components of the lifestyle they propose. On the other hand, Varyap presents ecological concerns and related issues as an important part of the lifestyle. NEF, however, proposes novel ideas on spatial flexibility and economy via folding rooms and modular housing. Some marketing strategies obviously have more significant relevance with the small/alternative households. Nevertheless, these three entrepreneurs do not propose groundbreaking ideas on the spatiality of the housing units themselves.

\section{Offbeat Spatialities}

The plan typologies of new generation small housing units of all three entrepreneurs (Nef, Dumankaya, Varyap) are mostly standard schemes. In the quest of revealing the spatial correspondences of peculiarities of small/alternative households, we have extricated a few offbeat small housing schemes sheltering potentials to adjust possible spatiotemporal needs of small/ alternative household types (especially one-person households and DINKS) in the lane of flow. We assert that these offbeat schemes tend to allow various possibilities for spatial appropriation and personalization. Moreover, within the theoretical frame of the study, they provide a fertile ground for debates on spatial experiments in housing schemes to address diverse household groups.

The first example is a two-room flat $(1+1 \mathrm{D})$ from NEF Kağıthane 08 Project (Figure 1). In this type, the space between the living room/kitchen and bedroom furnished as a separate dining zone might either be the extension of the social zone or the private zone (bedroom); or might even gain a more intimate segregated character of its own. This middle space/zone (among the other compact standard schemes) that is

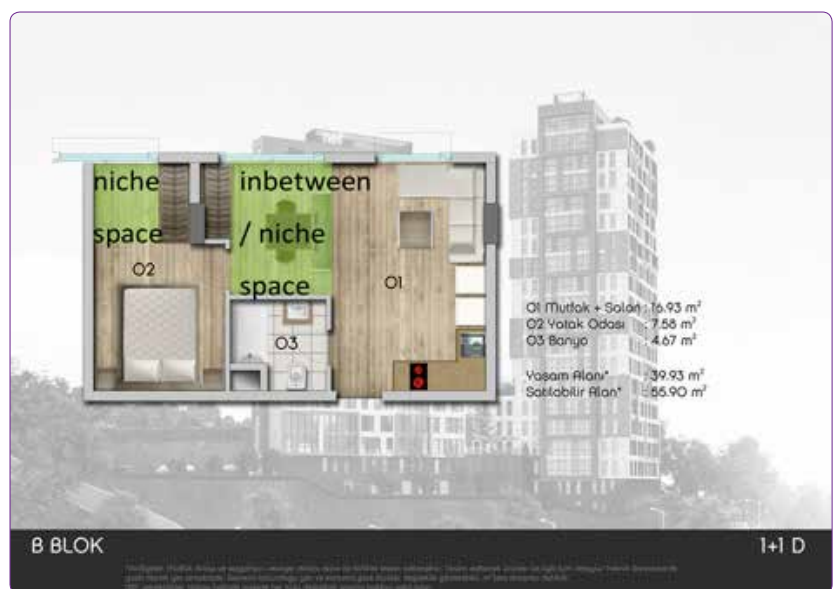

Figure 1. NEF Kağıthane 08, type 1+1 D. Source: Retrieved from http://www.nef.com.tr/nefkagithane08/ [Accessed 15.08.2014] 


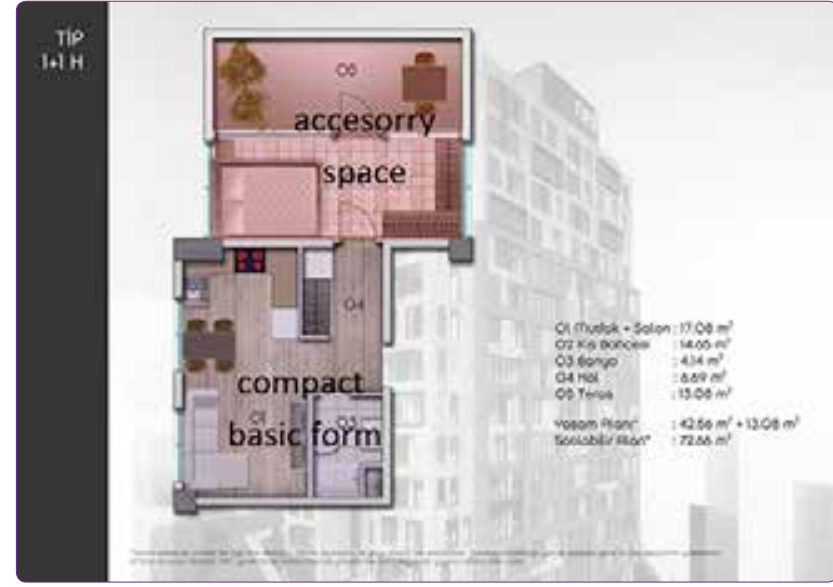

Figure 2. NEF Points 98 , type $1+1 \mathrm{H}$. Source: Retrieved from http://www.nefpoints.com/nefpoints98/ [Accessed 15.08.2014]

also the transition zone between two main spaces (living area and bedroom) has an in-between character with the two-way potential of ebb and flow. Moreover, with the current furnishing, it provides a loop in the main (living) space that also adds a niche character to it. Besides, space just next to the wardrobe has the characteristics of a niche-space, invoking a variety of potentials of usage.

NEF Points 98 Project also encompasses exceptional plan typologies as if some accessory spaces ${ }^{54}$ are interfering with typical compact basic form (mono-space) studio flats. In the sample (type 1+1 H) (Figure 2), the accessory space includes a winter garden and a $13 \mathrm{~m}^{2}$ terrace. The winter garden furnished as a bedroom is divided into two subspaces by the axiality of the corridor, which destroys the private character of the bedroom zone stretching from the entrance hall until the relatively public terrace zone.

In the sample (type 1+1I) (Figure 3), the organization logic of spaces, -compact basic form (mono-space) interfered with accessory space- shows similarities with the previous one. However, this time, a rather wider winter garden is furnished as a living space including the kitchen; the main block is divided with a partition involving the bedroom and the comparably large area implying a variety of uses such as a study/sitting corner/...etc. Keeping the prototype organization of mono-space (normally including kitchen and the main

\footnotetext{
${ }^{54}$ In housing literature, accessory units (also known as accessory apartments, guest apartments, in-law apartments, family apartments or secondary units) are defined as "supplementary housing that can be integrated into existing single family neighborhoods to provide a typically lower-priced housing alternative with little or no negative impact on the character of the neighborhood" Url 10. In this paper, the word 'accessory' has been interpreted and charged with new spatial meanings.
}

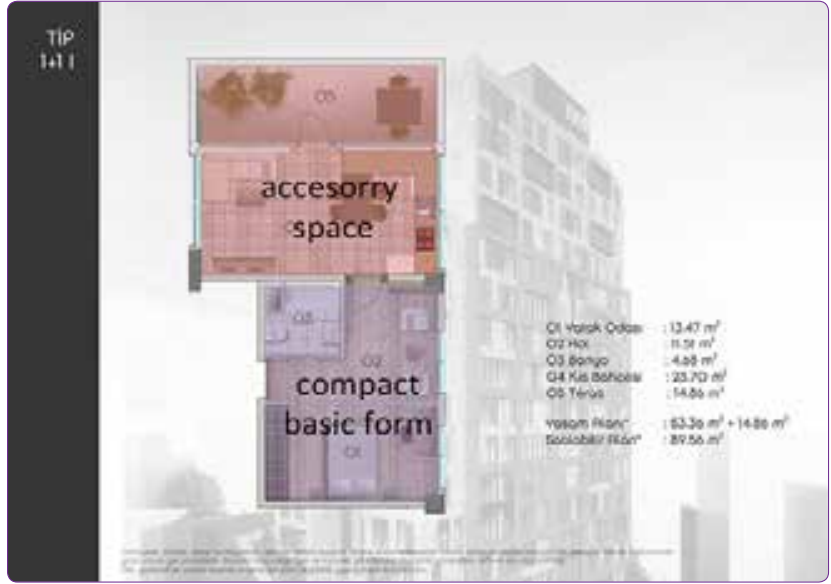

Figure 3. NEF Points 98, type $1+1$ l. Source: Retrieved from http://www.nefpoints.com/nefpoints98/ [Accessed 15.08.2014]

living area in the conventional schemes) would be the first to come to mind as in the previous example (type $1+1 \mathrm{H}$ ), but in (type $1+1 \mathrm{l}$ ), this perfect compactness is divided. In fact, it is totally dispersed and spatiality is perceived as two compartments: private night time usage and public day time usage. They demonstrate totally different characteristics and an unexpected location with respect to the entrance door.

As shall be followed from the plan (Figure 3), the main square form is organized -and therefore functions- as a hotel room and there is a major shift between public and private spheres of the house.

In these examples (type $1+1 \mathrm{H}$ and type $1+1 \mathrm{l}$ ), the compact forms and their centripetal character are formally and spatially deteriorated with the addition of accessory spaces which also imply a transition from inside to outside both semantically (considering the connotations of a winter garden) and physically since they end up with large terraces. Hence, space is folding from inside to outside.

A similar solution has been developed at Varyap Meridian. One interesting feature of the plan schemes in this project is the use of floor gardens in some small units (studio flats and 1+1 units) (Figure 4). Those spaces function similar to winter gardens of NEF Points; however, expressing them as attached/ extended spaces rather than accessory spaces due to their form and scale seems more reasonable. ${ }^{55}$ Floor gardens semantically evoke open space connotations just as winter gardens. However, they are mostly long and narrow enclosed spaces (on all sides) which might

\footnotetext{
${ }^{55}$ Attached/extended spaces don't offer a sequence of spaces within themselves and can't be recognized as separate entities formally as well.
} 


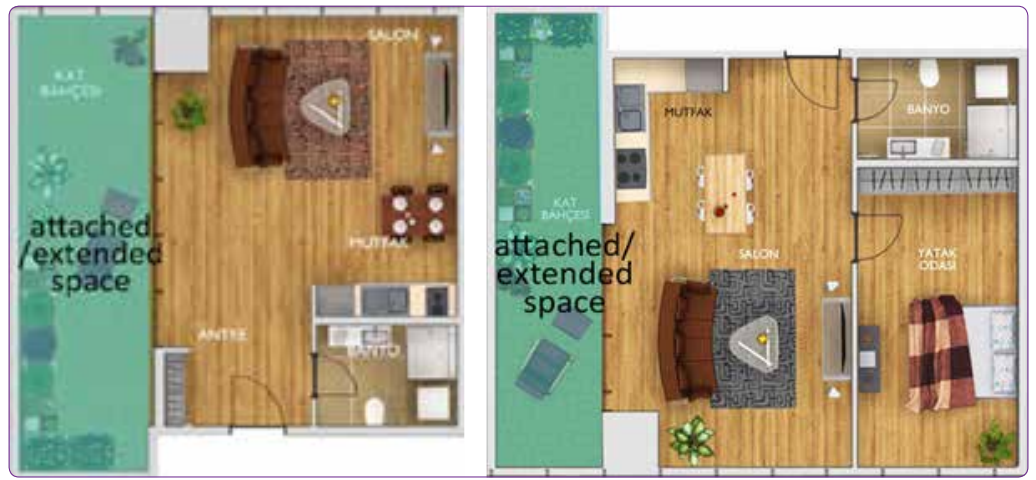

Figure 4. Varyap Meridian, studio with a floor garden (76,2 sqm²) (left) Varyap Meridian, $1+1$ unit with a floor garden $\left(93 \mathrm{sqm}^{2}\right.$ ) (right). Source: Retrieved from http://www.varyapmeridian.com/tr/rezidans/daire-planlari [Accessed 10.09.2014]

either be included in the main space and function as extensions of living-dining zone (breakfast niche, garden/green zone, etc.) or they might be segregated, divided and subdivided to function in more private/ intimate terms (bedroom/study room/corner, guest room/corner, etc.) according to the needs of the users. In the catalogs and on the website, floor gardens are both hatched as inside (timber) and outside spaces (green zone) which also imply their ambiguous character. Those spaces are introduced by the firm with a special emphasis on their multi-use potentials to customers during face-to-face conversations. The floor gardens overflow the boundaries of the main space at one of the narrow edges and gain the characteristics of a niche. These overflowing edges are cozier and more private spaces partially separated in visual and physical terms. Anyhow, floor gardens trigger the user to subvert and reorganize space and to think about the potential scenarios. It is also possible to say that due to their narrow and bizarre form, they create the sense that the main space is leaking.

Finally, $1+1.5$ units developed by Dumankaya in Ritim İstanbul Project are terminologically fairly recent on the market (Figure 5). Besides a living space with an open kitchen, this plan typology includes a half/semispace that is attached to the neighboring space while also becomes the extension of it. This attached space has been furnished as a study room; however, it has a myriad of becoming potentials as in the other/previous similar samples (Figure 4). Being only $5 \mathrm{~m}^{2}$, it cannot function as a separate space. There are no boundaries between the hall and half/semi-space; on the contrary, they have a mutual existence, and they multiply each other. The hall spatially and visually expands into the attached space to adjust the spatial and temporal necessities of the users. Such attached spaces are also open to spatial appropriation by the households.

\section{Concluding Remarks}

The main intention of this article is to incite thinking on the concept of spatiality that would speak to the needs and expectations of so far overlooked small/ alternative households. Departing from the point that space is a social construct and small/alternative households are in the range of communitas due to their marginal and inferior position in society, we assert that there is an enormous lack in the housing market in terms of taking advantage of the liminal, marginal and inferior aspects of these groups and to foster

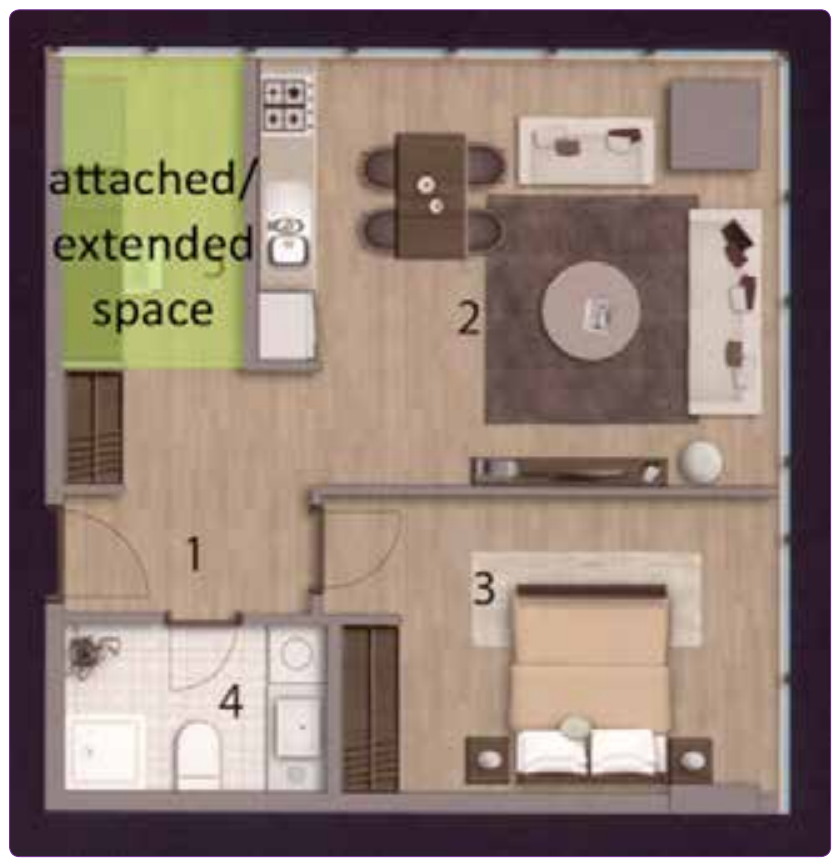

Figure 5. Dumankaya Ritim Istanbul 1+1,5 A2 Type. Source: Dumankaya Ritim Istanbul Catalog. 
novel ways of thinking on spatiality. Such debates and experiments would bear potentials to question and requestion the settled norms and to pave the way for more experimental spatial layouts.

Within the scope of this research, while reviewing the recent residential projects of three major entrepreneurs (Nef, Dumankaya and Varyap) mostly including small housing units, we have realized that, although they offer novel ideas in terms of marketing based on lifestyle promises, the plan schemes they propose are mostly standard. We extricated very few schemes that erode settled norms regarding plan typologies, and we thought that they were more prone to small/alternative households. Those non-standard small housing schemes have been examined in the pursuit of tracing the footprints of spatial implications and correspondences of peculiarities of these household types.

In the analyzed schemes, we have noticed niche (Figure 1), accessory (Figure 2 and 3 ) and attached/ extended (Figure 4 and 5) spaces. They all have the potential of affecting the conventional spatial sequences and creating zones for temporary appropriation and instant personalization. They are like the ebb and flow spaces having the potential of flowing and expanding due to 'moments' and 'events' within the life course. They also negotiate with Turner's manifestations of anti-structure: liminality (implying the betwixt and inbetween position, transitional/ambiguous stage), marginality and inferiority and their spatial expressions: The in-between, the edges and the beneath. Apparently, niche spaces with their in-between position and/ or connotations add liminal aspects to design schemes while accessory, attached/extended spaces at the edges of the compact forms bring in marginal aspects that contradict with the accepted norms in relation to both form and function. In the selected schemes, that have been named as offbeat, public and private relationships shift, space becomes more open to performative roles and acts of the potential inhabitants. These spaces do not impose strict norms, identities, roles, or spatial codes; on the contrary they pave the way for social and spatial negotiation, through their ability to adjust possible spatial and temporal necessities, and being compatible with the peculiarities of the household types that mostly perform more rapid changes in their life course. Such experimental spatial layouts are predominantly normless; they have even false/defective, redundant, awkward, and imperfect aspects for those who are accustomed to settled norms. Although it still is not clear whether they are the intentional outcomes or simply unintentional results of the de- sign process, they still incite us thinking on spatiality. Henceforth, the housing market should notice the potentials of non-standard spatialities along with lifestyle design to attract diverse small households. The increasing ratio of small/alternative households in the society and their prospective housing demand necessitate more research on theoretical aspects of spatiality and spatial analysis of the new generation small housing units. Such research might encourage all the agencies responsible for housing production namely institutions, designers, developers, and households for exploring and demanding offbeat spatialities.

\section{References}

Ahrentzen, S. and Frank A.K. (1991) New Households New Housing, New York, Van Nostrand Reinhold.

Balamir, M. (1996) "Konut Sisteminin Bir Diğeri: Küçük Hanehalkları", E. Konut (Ed.) Diğerlerinin Konut Sorunları, Ankara, TMMOB Mimarlar Odası, p. 518-532.

Beck, U. (1992) Risk Society. Towards a New Modernity, (trans. By. M. Ritter), London, Newbury Park, California, Sage Publications.

Behar et al. (1999) Turkey's Windows of Opportunity. Demographic Transition Process and its Consequences, İstanbul, Lebib Yalkım Yayınevi.

Bell, D. and Hollows, J. (ed.) (2006) Historicising Lifestyle: Mediating Taste, Consumption and Identity from 1990's to 1970 's, Burlington USA, Ashgate Publishing Company.

Berger, L. M, Heintze, T, Naidich W. B., Meyers, K. M (2008) "Subsidized Housing and Household Hardship among Low-Income Single-Mother Households", Journal of Marriage and Family, Vol 70/4, p. 934-949. Retrieved from URL: http://www.jstor.org/stable/40056309.

Bhabha, K.H. (2004) The Location of Culture, London and New York, Routledge.

Bourdieu, P. (1999) Distinction. Social Critique of the Judgement of Taste, (Trans. By R. Nice), London, Routledge.

Chaney, D. (1999) Yaşam Tarzları, (çev. İ. Kutluk), Ankara, Dost Kitabevi Yayınları.

Clapham, D. (2005) The Meaning of Housing. A pathways approach, Bristol, The Policy Press.

Després, C. (1993) "A Hybrid Strategy in a Study of Shared Housing", Ed.: E. G. Arias, Meaning and Use of Housing, Avery, Aldershot, p. 381-403.

Duben, A. and Behar, C. (1996) İstanbul Haneleri. Evlilik, Aile ve Doğurganlık 1880-1940, İstanbul, İletişim Yayınları.

Dumankaya, A. (2013) Panel in YEM Housing Conference, 21 November, 2013.

Fisher, R. M. and Graham, J. W. (1974). Housing Demand by One-Person Households, Land Economics, Vol.50. No.2, p. 163-168. Retrieved from URL: http://www.jstor.org/ stable/3145366 [Accesed 08.07.2015].

Frank K. A., Ahrentzen, S. (ed) (1991) New Households and New Housing, New York, Van Nostrand Reinhold.

Glass, R. and and Davidson F. G. (1951) "Household Structure and Housing Needs", Population Studies, Vol. 4 No. 
4 (March 1951) p. 395-420. Retrieved from Url: http:// jstor.org/stable/2172391 [Accesed 8 July 2015].

Gülersoy, N. Z. \& Sarıkaya, Ö. (2011) "Toplu Konut Uygulamalarında Ölçek Büyümesi", Konut Sempozyumu, Istanbul, TMMOB Istanbul Odası İstanbul Büyükkent Şubesi, p. 185-219.

Gülmez Ünsal, N. (2008) Metropolde Çeşitlenen Hanehalkları ve Konut, Yayımlanmamış Doktora Tezi (Unpublished doctoral dissertation), ITÜ Fen Bilimleri Enstitüsü.

Gürlesel, F. C., (2012) GYODER (Gayrimenkul Yatırım Ortaklığı Derneği), 2023 Vizyonunda Gayrimenkul Sektörü, İstanbul, GYODER Iktisadi İşletmesi. Retrieved from http://gen.tobb.org.tr/ggnot/images/bilgi_notu/181_ S1312010GOC.pdf [Accessed 14. 04.2014]

Heath, S. and Kenyon, L. (2001) "Single Young Professionals and Shared Household Living", Journal Of Youth Studies, $4 / 1,83-100$

Hooks, B. (1990) Yearning. Race Gender and Cultural Politics, Boston, South End Press.

Jones, G. (2000) "Experimenting with Households and Inventing 'Home'", International Social Science Journal, 52/164, 183-184. Retrieved from Url: http://onlinelibrary.wiley.com/doi/10.1111/1468-2451.00250/epdf [Accesed 8 July 2015].

Komut, E. (ed) (1996) Diğerlerinin Konut Sorunları, TMMOB Mimarlar Odası, Ankara.

Lash, S. And Urry, J. (1994) Economics of Sign and Space, London, Sage Publications.

La Shure, C. (2005) What is Liminality?. Retrieved from http://www.liminality.org/about/whatisliminality/ [Accessed 25.09.2014]

Lefebvre, H. (1991) The Production of Space (translated by D. Nicholson-Smith), Malden-Oxford-Victoria, Blackwell Publishing, p. 26-27

Mugerauer, R. (1994) "A Homecoming. Design on Behalf of Place (chapter 10)", Interpretations on Behalf of Space. Environmental Displacements and Alternative Responses, Albany, State University of New York Press, p. 162186.

Roberts, M. (2014) Lefebvre and History of Space. Retrieved from http://www.rudi.net/books/12219 [Accessed 25.09.2014].

Soja, E. (1996) "Exploring the Spaces that Difference Makes: Notes on the Margin", Thirdspace, Oxford, Blackwell Publishers, p. 82-105.

Tomlinsen, M. (2003) "Lifestyle and Social Class", European Sociological Review, Vol. 19, No. 1, p. 97-111. Retrieved from hhtp://www.jstor.org/stable/3559477. [Accesed 13 July 2015).

Turner, V. (1991) The Ritual Process. Structure and AntiStructure, Ithaca, NY, Cornell University Press.

United Nations (1977) Housing For Special Groups, A Seminar of the United Nations Economic Commision for Europe, Pergomen Press.

Yavuz, S. \& Yüceşahin, M.M. (2012) Türkiye'de Hanehalkı Kompozisyonlarında Değişimler ve Bölgesel Farklılaşmalar, Sosyoloji Araştırması Dergisi, Vol: 15 /1, p. 76-116.

\section{Internet Sources}

Url 1 http://www.hurriyet.com.tr/ekonomi/28066421 [Accesed 6 July 2015]

Url 2 http://chpcny.org/our-projects/single-person-households/ [Accesed 7 July 2015]

Url 3 http://www.nefhalic.com/proje-Hakkinda.aspx [Accessed 20 August.2014]

Url $4 \mathrm{http} / / /$ www.nef.com.tr/kurumsal_nedir.php. [Accessed 25 August 2014]

Url 5 http://www.nef.com.tr/kurumsal_hikayesi.php [Accessed 25 August 2014]

Url 6 http://www.dumankaya.com/Sayfalar/Kurumsal/Tarihce.aspx [Accessed 18 September 2014].

Url 7 http://www.dumankaya.com/DumankayaHifit/HI_FIT_ katalog.pdf [Accessed 27 August 2014].

Url 8 http://www.dumankaya.com/DumankayaHifit/HOME_ FIT_katalog.pdf [Accessed 27 August 2014].

Url 9 http://www.varyapmeridian.com/tr/konsept/adanzye-degisim [Accessed 29 August 2014].

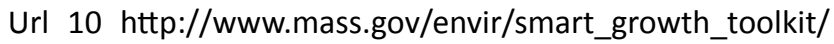
pages/mod-adu.html [Accessed 28 September 1012] 